\title{
ЗАЩИТА РЫНОЧНОЙ КОНКУРЕНЦИИ ОРГАНАМИ МЕСТНОГО САМОУПРАВЛЕНИЯ В РОССИИ
}

Аннотация. Предметом исследования является система правовых норм и институтов, регулирующих рыночную конкуренцию на муниципальном уровне в России. Объектом исследования являются общественные отношения, возникающие в процессе осуществления экономической деятельности между хозяйствующими субъектами и органами местного самоуправления. Автором рассмотрены базовые категории, касающиеся законодательства о конкуренции. Теоретические выводы, содержащиеся в диссертационном исследовании, формируют комплексное представление о конституционно-правовом и муниципальном регулировании конкуренции в России и закладывают основы для дальнейшего его изучения. Методологической основой исследования являются общенаучные и частно-научные методы познания общественных процессов. В процессе исследования использовались системно-структурный, сравнительно-правовой, исторический, логический, формально-юридический подходы. Их применение позволило автору исследовать рассматриваемую проблему во взаимосвязи, целостности, всесторонне и объективно. Автором использован принцип единства теории и практики, при котором анализ юридических принципов осуществлялся во взаимосвязи с экономическими, политическими и иными общественными отношениями. Автором проанализировано законодательство, регулирующее полномочия органов местного самоуправления в сфере предпринимательской деятельности, выявлены недостатки правового регулирования в указанной сфере, предложены возможные направления в сфере расширения полномочий органов местного самоуправления в сфере защиты конкуренции. По мнению автора необходимо придать большую автономность органам местного самоуправления в сфере защить рыночной конкуренции путем использования принципа субсидиарности в распределении компетенции.

Ключевые слова: муниципальные учреждения, местный бюджет, предпринимательская деятельность, органы местного самоуправления, принцип субсидиарности, муниципальное право, реформирование, Рыночная конкуренция, конституционное регулирование, конституционное гарантирование.

Abstract. The research subject is the system of legal norms and institutions regulating market competition on the local level in Russia. The research object includes social relations emerging in the sphere of economic activity between economic entities and local authorities. The author considers the basic categories of the competition legislation. Theoretical conclusions of the study form a complex understanding of the constitutional and municipal regulation of competition in Russia and lay the groundwork for its further studying. The research methodology is based on general scientific and specific methods of social processes cognition. The author applies the system-structural, comparativelegal, historical, logical and formal-legal approaches. They help study the problem in interconnection, integrity, objectively and comprehensively. The author uses the principle of unity of theory and practice, analyzes the legal principles in interconnection with economic, political and other social relations. The author analyzes the legislation, regulating the authorities of local governments in the sphere of entrepreneurship, reveals the drawbacks of legal regulation in this sphere, and offers the possible directions of broadening of powers of local governments in the sphere of competition protection. In the author's opinion, it is necessary to grant more autonomy to local governments in the sphere of competition protection by means of the subsidiarity principle in the distribution of authorities.

Key words: constitutional guaranteeing, constitutional regulation, municipal institutions, local budget, entrepreneurship, local authorities, subsidiarity principle, municipal law, reforming, market competition.

C огласно Конституции РФ 1993 г. в качестве основы развития местного самоуправления использована англосаксонская модель, при которой органы местного самоуправления (далее - ОМСУ) не входят в систему органов государственной власти, а муниципальная автономия является одной из основ конституционного строя. Федераль- ный закон «Об общих принципах организации местного самоуправления в Российской Федерации» от 28.08.1995 г. № 154-Ф3 фактически нивелировал вышеуказанные полномочия ОМСУ, поставив их в организационную и финансовую зависимость от органов государственной власти в субъектах. По настоящее время ни Конституция РФ, ни иные норма- 


\section{Административное и муниципальное право 7 (103) • 2016}

тивно-правовые акты не определяют роль и место местного самоуправления в системе государственного устройства, а также основы взаимодействия государственной власти и ОМСУ.

Последующая муниципальная реформа, начавшаяся с принятия Федерального закона «Об общих принципах организации местного самоуправления в Российской Федерации» от 06.10.2003 г. № 131-ФЗ (далее - ФЗ № 131-Ф3), фактически установила в РФ смешанную модель, но не с уклоном к континентальной или англосаксонской модели, а к социалистической, которая обусловлена чрезмерной централизацией власти. Семь из 10 полномочий, предусмотренных Европейской хартией (в т.ч. по установлению местных налогов) не нашли отражения в данном законе. Представляется, что такая «смешанная» модель лишает ОМСУ какой-либо инициативы, в том числе по развитию предпринимательской деятельности и защите конкуренции, так как любые действия или решения ОМСУ должны проходить процедуру согласования с органами государственной власти субъекта, которые в свою очередь также фактически лишены самостоятельности перед федеральным центром. Кроме того, ОМСУ фактически «встроены» в вертикаль государственной власти и связаны так называемой «партийной дисциплиной», что противоречит самому смыслу местного самоуправления и конституционным принципам его организации.

Централизованное федеральное регулирование разграничения вопросов местного значения и их исчерпывающий перечень в федеральном законодательстве обусловлены централизованной бюджетной системой и централизованным регулированием межбюджетных отношений. В рамках современной реформы продолжается сокращение перечня вопросов местного значения, в том числе тех, которые составляют сущность местного самоуправления. Возможность постоянных изменений законодательства в сфере полномочий местного самоуправления, осуществляемых без участия таких органов, также свидетельствует об отсутствии стабильности правового регулирования в данной сфере, нарушает принцип правовой определенности и создает почву для ущемления прав ОМСУ.

В ст. 50 Ф3 № 131-Ф3 определен перечень имущества, которое может находиться в собственности ОМСУ. Однако перечни вопросов местного значения, указанные в ст. ст. 14-16 Ф3 № 131-Ф3 не соотносятся с перечнем имущества. В частности, не обеспечены имуществом такие вопросы как оказание населению услуг связи, общественного питания, торговли, бытового обслуживания, содействие в развитии сельскохозяйственного производства, расширение рынка сельскохозяйственной продукции, сырья и продовольствия. В свою очередь установление закрытого перечня муници- пального имущества ограничивает возможности ОМСУ по созданию условий для развития предпринимательства и построению эффективной экономики на муниципальном уровне.

Несмотря на установленную Конституцией возможность участия в поддержке и защите конкуренции государственных органов субъектов РФ и ОМСУ, последние фактически не могут реализовать свои полномочия в должной мере в силу ограниченного набора инструментов и финансовой зависимости от федерального центра. По сути, ОМСУ находятся в тотальной зависимости от государства, т.к. получают большую часть денежных средств в рамках целевых программ. В настоящее время к федеральным относится 8 видов налогов, к региональным - 3, к местным - 2. Таким образом, полномочия ОМСу не обеспечены деньгами, в связи с чем, ОМСУ лишены какой-либо активности в решении вопросов местного значения, а также вынуждены при формировании бюджета руководствоваться приоритетами, определяемыми из федерального центра.

Согласно ч. 1 ст. 132 Конституции РФ органы местного самоуправления самостоятельно формируют, утверждают и исполняют местный бюджет. Однако данное положение Конституции РФ нивелировано федеральным законодательством, в результате чего, ОМСУ фактически встроены в исполнительную ветвь государственной власти, а местные бюджеты в структуру федеральной бюджетной системы. Представляется, что только при наличии экономической основы местное самоуправление сможет реально осуществлять возложенные на него функции. Местное хозяйство является предпосылкой создания правовых рыночных отношений, формирования многоукладной децентрализованной экономики, конкурентного рынка. ОМСУ должны быть вправе и одновременно обязаны создавать благоприятные конкурентные условия осуществления хозяйственной деятельности, сами участвовать в рыночной конкуренции, помогать населению в реализации права на свободную предпринимательскую деятельность. Именно муниципалитеты должны стать первым уровнем по защите конкурентных начал в РФ.

Развитие данного института будет соответствовать позиции Президента РФ, который в ежегодном послании Федеральному Собранию в 2015 г. отметил, что государство и бизнес являются равными партнерами, а хозяйствующие субъекты должны иметь стимул для развития своей предпринимательской деятельности. Качество и эффективность принимаемых правовых решений является одним из ключевых условий экономического развития государства. Регулирование должно быть нацелено на конкретные проблемы (точечное), эффективно применяться, быть справедливым и стимулировать 
инновации. Такая система регулирования должна минимизировать разрывы в регулировании и чрезмерно регулирование. Однако существенное значение имеет определение метода регулирования с точки зрения его целесообразности. Хозяйственные потери предпринимателей начинаются тогда, когда органы государственной или муниципальной власти отдают чрезмерное предпочтение экономическим или административным методам.

Для развития и защиты конкуренции на конкретных территориях необходимо сильное, независимое и финансово самостоятельное местное самоуправление. Именно через экономическую основу достигается самостоятельность местного самоуправления в вопросах местного значения. Существенным недостатком также является отсутствие межмуниципального сотрудничества. Между тем, именно оно является одним из условий экономического развития муниципалитетов, а также участия в хозяйственной деятельности. Вышеуказанная ситуация еще раз доказывает необходимость защиты рыночной конкуренции от недобросовестных действий как хозяйствующих субъектов, так и государственных органов. В первую очередь, такую защиту на местах должны обеспечивать ОМсУ.

Конституционное признание и гарантирование институтов федерализма и местного самоуправления в различных странах еще не свидетельствует о единстве подходов к пониманию их роли и организации. Формальное конституционное закрепление принципа федерализма и обособление ОМСУ от государства и системы органов государственной власти не согласуется с постоянным урезанием полномочий таких органов, их финансовой и организационной зависимостью от федерального центра. С целью преодоления возникшего дисбаланса между конституционными положениями и реальным положением дел представляется необходимым обратиться к зарубежному опыту, не с целью его копирования и бездумной имплементации, но с целью его анализа и выработки собственных решений. Наряду со справедливой критикой безоглядного заимствования зарубежного опыта высказываются суждения об ошибочности ориентирования на европейский опыт в целом. Представляется, что подобные утверждения являются ошибочными. В первую очередь, в качестве контраргумента следует указать на то, что Европейская хартия, содержащая демократические стандарты, является частью российской правовой системы. Именно в данном документе содержатся основные положения, нашедшие отражение в конституционных основах организации ОМСУ в демократических государствах. Во-вторых, дореволюционное развитие городского и земского самоуправления являлось результатом творческой адаптации европейского (в первую очередь германского) опыта организации местного (коммунального) самоуправления. Исходя из анализа произошедших реформ, следует, что законодатель полностью отошел от модели местного самоуправления, закрепленной в Конституции РФ. Представляется необходимость использования принципа субсидиарности не только во взаимоотношениях федеральных и региональных органов, но и во взаимоотношениях с ОМСУ. Для этого в первую очередь необходимо закрепление такого принципа в конституционном законодательстве.

\section{Библиография:}

1. Конституция Российской Федерации" (принята всенародным голосованием 12.12.1993) (с учетом поправок, внесенных Законами РФ о поправках к Конституции РФ от 30.12.2008 N 6-ФКЗ, от 30.12.2008 N 7-ФКЗ, от 05.02.2014 N 2-ФКЗ, от 21.07.2014 N 11-ФКЗ) // "Собрание законодательства РФ, 04.08.2014, № 31, ст. 4398.

2. $\quad$ О государственных и муниципальных унитарных предприятиях: Федеральный закон от $14.11 .2002 \mathrm{~N} 161-Ф 3$ (ред. от 23.11.2015) // "Российская газета", N 229, 03.12.2002.

3. О защите конкуренции: Федеральный закон от 26 июля 2006 г. № 135-Ф3 (ред. от 05.10.2015) // "Собрание законодательства РФ", 31.07.2006, N 31 (1 ч.), ст. 3434.

4. Об общих принципах организации местного самоуправления в Российской Федерации: Федеральный закон от 06.10.2003 N 131-Ф3 (ред. от 30.12.2015) // "Парламентская газета", N 186, 08.10.2003.

5. Самсонов А.И. Основные направления муниципальной инвестиционной деятельности: правовой аспект. // Право и политика. - 2015. - 12. - С. 1701 - 1705. DOI: 10.7256/1811-9018.2015.12.17061.

\section{References (transliterated):}

1. "Konstitutsiya Rossiiskoi Federatsii" (prinyata vsenarodnym golosovaniem 12.12.1993) (s uchetom popravok, vnesennykh Zakonami RF o popravkakh k Konstitutsii RF ot 30.12.2008 N 6-FKZ, ot 30.12.2008 N 7-FKZ, ot 05.02.2014 N 2-FKZ, ot 21.07.2014 N 11-FKZ) // "Sobranie zakonodatel'stva RF, 04.08.2014, № 31, st. 4398.

2. $\quad 0$ gosudarstvennykh i munitsipal'nykh unitarnykh predpriyatiyakh: Federal'nyi zakon ot 14.11.2002 N 161-FZ (red. ot 23.11.2015) // "Rossiiskaya gazeta", N 229, 03.12.2002.

3. 0 zashchite konkurentsii: Federal'nyi zakon ot 26 iyulya 2006 g. № 135-FZ (red. ot 05.10.2015) // "Sobranie zakonodatel'stva RF", 31.07.2006, N 31 (1 ch.), st. 3434.

4. $\quad$ Ob obshchikh printsipakh organizatsii mestnogo samoupravleniya v Rossiiskoi Federatsii: Federal'nyi zakon ot 06.10 .2003 N 131-FZ (red. ot 30.12.2015) // "Parlamentskaya gazeta", N 186, 08.10.2003.

5. Samsonov A.I. Osnovnye napravleniya munitsipal'noi investitsionnoi deyatel'nosti: pravovoi aspekt. // Pravo i politika. 2015. - 12. - C. 1701 - 1705. DOI: 10.7256/1811-9018.2015.12.17061. 